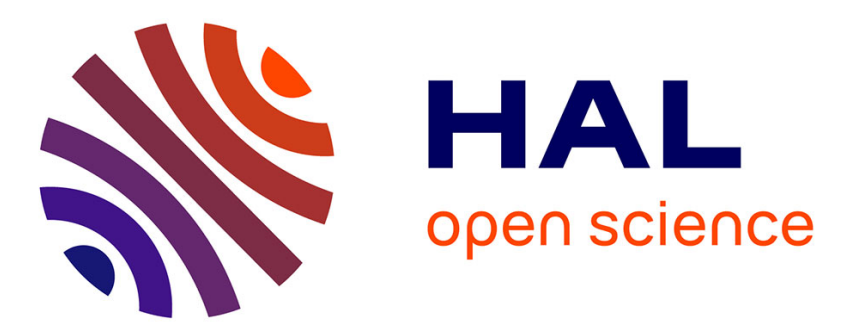

\title{
A new method for test chip and single 40nm NOR Flash cell electrical parameters correlation using a CAST structure
}

T. Kempf, V. Della Marca, P. Canet, A. Regnier, P. Masson, Jean-Michel Portal

\section{To cite this version:}

T. Kempf, V. Della Marca, P. Canet, A. Regnier, P. Masson, et al.. A new method for test chip and single 40nm NOR Flash cell electrical parameters correlation using a CAST structure. 2018 International Symposium on VLSI Technology, Systems and Application (VLSI-TSA), Apr 2018, Hsinchu, Taiwan. 10.1109/VLSI-TSA.2018.8403859 . hal-01900783

\section{HAL Id: hal-01900783 https://hal.science/hal-01900783}

Submitted on 29 Jul 2020

HAL is a multi-disciplinary open access archive for the deposit and dissemination of scientific research documents, whether they are published or not. The documents may come from teaching and research institutions in France or abroad, or from public or private research centers.
L'archive ouverte pluridisciplinaire HAL, est destinée au dépôt et à la diffusion de documents scientifiques de niveau recherche, publiés ou non, émanant des établissements d'enseignement et de recherche français ou étrangers, des laboratoires publics ou privés. 


\title{
A new method for test chip and single 40nm NOR Flash cell electrical parameters correlation using a CAST structure
}

\author{
T. Kempf ${ }^{1}$, V. Della Marca ${ }^{2}$, P. Canet ${ }^{2}$, A. Regnier ${ }^{1}$, P. Masson ${ }^{3}$, J.-M. Portal ${ }^{2}$ \\ *STMicroelectronics, Rousset, France \\ **IM2NP, Aix-Marseille University, Marseille, France \\ ***EpOC / Nice Sophia-Antipolis University, Biot, France \\ E-mail: thibault.kempf@st.com
}

\begin{abstract}
In this work we present a method to find a correlation between the measurements on single 40nm embedded Flash memory cell, and the $512 \mathrm{kB}$ test chip electrical results. The bridge between these two structures is the cell array stress test (CAST). We are able to simulate the behavior of a $10 \mathrm{~kb}$ and a $1 \mathrm{Mb}$ CAST structures. The parasitic resistances are taken into account, as well as, the testchip distributions for the modeling. The aim is to reduce the time of test obtaining preliminary information concerning the fabrication process and the memory yield at the parametric test level and before the electrical wafer sorting.
\end{abstract}

\section{INTRODUCTION}

As reliability margins are dropping like rocks, an extrinsic approach of embedded Flash memory is compulsory to assess and validate the mission profile and its reliability requirements. To accelerate technology development, single test structure characterizations shall bring preliminary results about the memory extrinsic behaviors which would be confirmed afterward on test chip. In this paper, we propose a method to model the drain current-gate voltage $\left(I_{D}-V_{G}\right)$ characteristics of a memory cells array using the results obtained on a $512 \mathrm{kB}$ test chip. The aim is to predict the distribution of memory cells inside a cell array stress test $[1,2]$ and its shape (intrinsic and extrinsic population as in [3] or [4]) with a single $\mathrm{I}_{\mathrm{D}}-\mathrm{V}_{\mathrm{G}}$ characteristic. The measurement are in general impacted by the test structure design $[5,6]$, thus to reach the goal, we considered the contribution of the CAST access resistance. Moreover we are able to build with our model, the threshold voltage distributions, that can be used for the CAST behavior study.

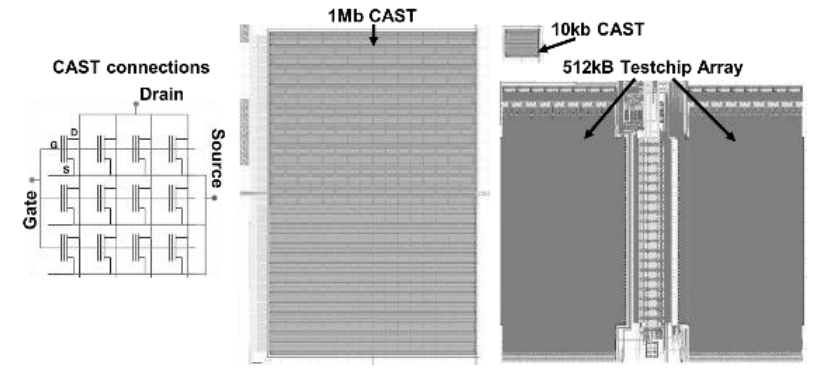

FIGURE 1. From left to right: CAST architecture, 1M cells and 10k CAST devices, and $512 \mathrm{kB}$ test chip memory array.

\section{DEVICE DESCRIPTION AND EXPERIMENT}

Our memory is a self-aligned polysilicon embedded Flash processed in a $40 \mathrm{~nm}$ technology node on $300 \mathrm{~mm}$ wafer. In the CAST structure the cells are connected in parallel and the biasing circuits are not present. Two CAST configurations are used with different size: (i) $1 \mathrm{M}$ cells, which represents a quarter of test chip memory capacity, and (ii) 10k cells (Fig.1). Thanks to the arrays architecture, the measurements of one of them can be separated in 4 cell populations, limiting the problem of current compliance and voltage drop during the electrical characterizations. The test chip has been already described in [7]. It contains $512 \mathrm{kB}$ of memory with the logic and high voltage circuits needed to access, program, erase and read the memory. Moreover it has all the functions associated to the macrocell testing such as BIST (Built-In-Self-Test), distribution, DMA (Direct Memory Access), internal voltage monitoring. The threshold voltages $\left(\mathrm{V}_{\mathrm{T}}\right)$ are extracted from $\mathrm{I}_{\mathrm{D}}-\mathrm{V}_{\mathrm{G}}$ of single cell measurements, while the test chip distribution is obtained by the reading with SPI protocol of a memory array and the application of an analog voltage on the control gate $\left(\mathrm{V}_{\mathrm{G}}\right)$ of the cells. The switching of sense circuits occurs when $\mathrm{V}_{\mathrm{T}}=\mathrm{V}_{\mathrm{G}}$, this allows to achieve quickly

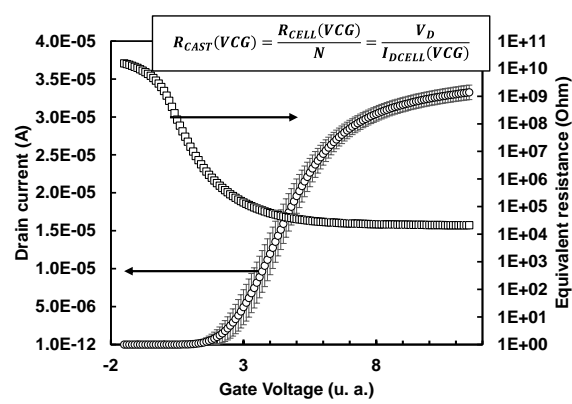

FIGURE 2. Drain current voltage characteristics of 18 single cells used for CAST model. Cell equivalent resistance is then used to compute CAST equivalent resistance depending on $\mathrm{N}$, the number of memory cell in the CAST.

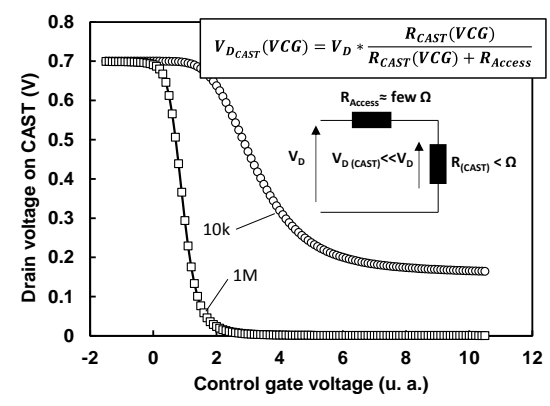

FIGURE 3. Drain voltage drop at CAST contact due to access resistance of metal line and the resulting voltage divider circuit. This result ensues from the fitting of modelled and experiemental CAST IdVg.

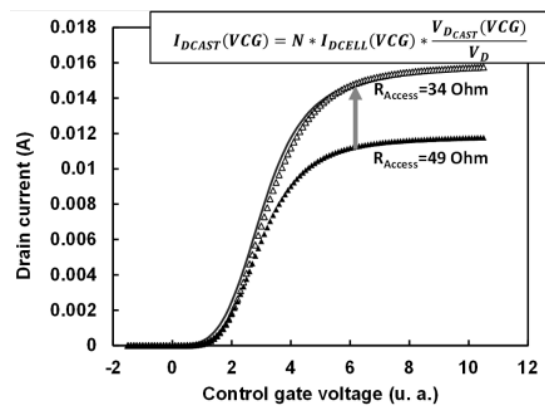

FIGURE 4. CAST drain current is computed considering the drain drop voltage evaluated in Fig.3 and that all CAST memory cell see the same drain voltage. Access resistance calculate by layout and metal lines resistivity is tuned to obtain the same $I_{D}$. 


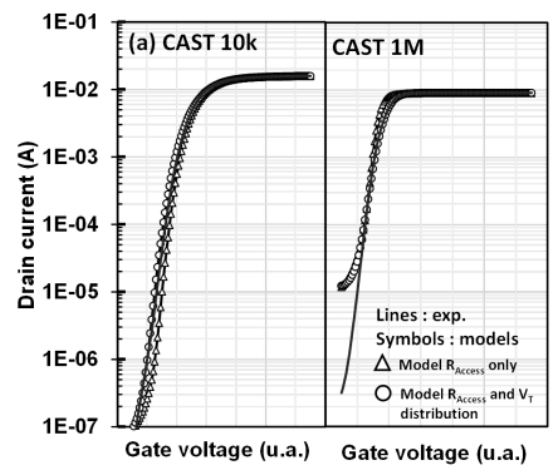

FIGURE 5. Model (symbols) and experimental (lines) drain current of 10k and 1M CAST in log (a) and linear (b) scales. Model with $\mathrm{R}_{\text {Access }}$ and $\mathrm{V}_{\mathrm{T}}$ dispersion reproduce best the knee at high current for $1 \mathrm{M}$ and the subthreshold slope of $10 \mathrm{k}$. Around $10^{-5} \mathrm{~A}$, the modelled drain current split from the experiments because of the noise floor of the single cell characterisitics used for the model in Fig. 2.

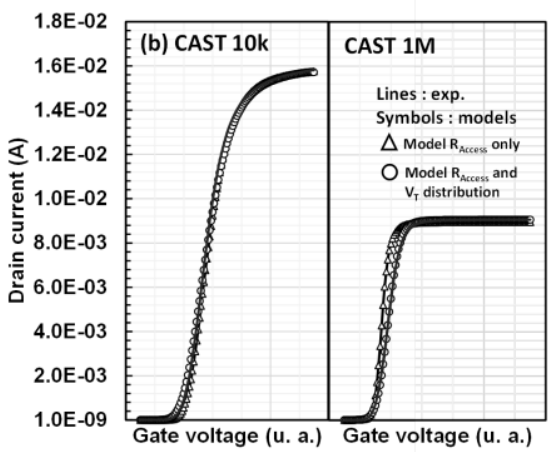

a distribution with a lower mean $\mathrm{V}_{\mathrm{T}}$ and a dispersion larger than

\section{parst} distribution close to the experiments.

\section{CAST CONTACT RESISTANCE MODELLING}

First, the goal is to approach the $\mathrm{I}_{\mathrm{D}}-\mathrm{V}_{\mathrm{G}}$ of CAST with a single memory cell characteristic (Fig. 2). To do that, it is necessary to estimate the internal memory matrix resistances $\left(\mathrm{R}_{\mathrm{CAST}}\right)$. We used the model presented in $[5,6]$, in order to evaluate the voltage drop at drain and source terminals of all transistors in the array. (Fig. 3). As shown in Fig. 4, the CAST characteristic can be obtained at first approximation, tuning the metal line resistance from the drain and source pads to the memory array $\left(\mathrm{R}_{\text {Access }}\right)$. At this point we have a good fitting between the CAST measurements and simulated $I_{D}-V_{G}$. However the knee around the $\mathrm{I}_{\mathrm{D}} @ \mathrm{~V}_{\mathrm{T}}$ for 1M CAST (Fig. 5a and 5b) is too bent to be simulated by considering only $I_{D}$ tuning, this effect highlights the approximation at first place of a unique threshold voltage. The same observation can be done on the subthreshold current modelling of 10k CAST (Fig. 5a and 5b).

\section{MODEL WITH THRESHOLD VOLTAGE DISTRIBUTION}

To obtain a good agreement between experimental data and simulated $\mathrm{I}_{\mathrm{D}}-\mathrm{V}_{\mathrm{G}}$ of CAST, it is necessary to take into account the Gaussian distribution of threshold voltage in a large array of memory transistors. Erase threshold voltage distribution are extracted from testchip and modelled as a Gaussian shape distribution (Fig. 6). Then the $\mathrm{I}_{\mathrm{D}}-\mathrm{V}_{\mathrm{G}}$ is modelled by adding the drain current of each cell $\mathrm{V}_{\mathrm{T}}$ pondered by the occurrence of it as described in:

$$
I_{D C A S T}(V C G)=\sum_{V_{C G \min }}^{V_{C G \max }} f_{V_{C G}=V_{T}}(V G) * \psi_{V_{C G}}
$$

Where $\Psi_{\mathrm{VCG}}$ represents the Gaussian distribution of $\mathrm{V}_{\mathrm{T}}$ from $\mathrm{V}_{\mathrm{CGmin}}$ to $V_{C G m a x}$ and $f_{V C G=V T}$ is the single cell $I_{D}-V_{G}$ shifted to obtain $\mathrm{V}_{\mathrm{T}}=\mathrm{V}_{\mathrm{G}}$. The modelling gives a perfect reproduction of each region of CAST $\mathrm{I}_{\mathrm{D}}-\mathrm{V}_{\mathrm{G}}$ without tuning much the distribution parameter as described Fig. 5a and 5b. This is clearly described in Fig. 7(a) and Fig. 7(b), where the log of simulated and experimental drain current tends to follow a linear fits. By introducing the $\mathrm{V}_{\mathrm{T}}$ distribution, a best fitting is achieved at low current for 10k (subthreshold area) and at high current for $1 \mathrm{M}$ CAST (threshold voltage area). However by looking at the distribution used for fitting in Fig. 5, even if the 10k $\mathrm{I}_{\mathrm{D}}-\mathrm{V}_{\mathrm{G}}$ modelling uses a Gaussian distribution with parameters near to
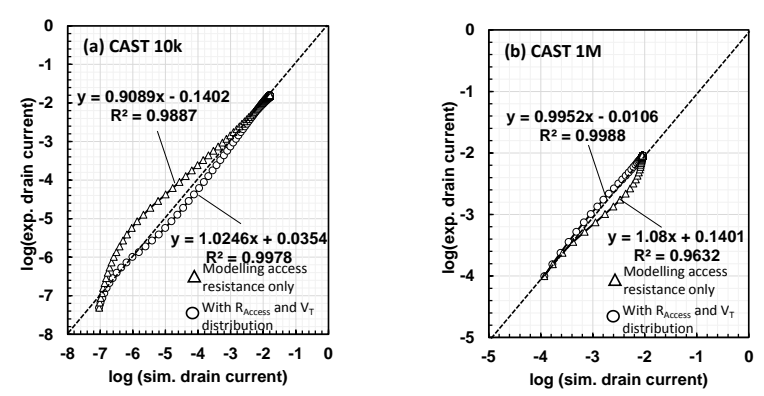

FIGURE 7. Correlation of log of drain current from model and experimental of $10 \mathrm{k}$ and $1 \mathrm{M}$ CAST device. Ideal correlation is shown in doted lines. Model with $R_{A}$ and $V_{T}$ yields the best fitting for every current magnitude compared to model with $\mathrm{R}_{\mathrm{A}}$ only.

expected. Thus, when modelling large CAST such as $1 \mathrm{M}$, the voltage drop on the CAST lines has to be considered as a first-order contributor to the dispersion [6].

\section{CONCLUSION}

The Cell Array Stress Test structure is well representative to testchip array and thus it gives useful information about both intrinsic and extrinsic cells population. In this paper, we show that intrinsic erased population can easily be modelled using single cell characterization and the threshold voltage distribution from our $512 \mathrm{kB}$ test chip considering the access resistance. However, for large CAST (here $1 \mathrm{M}$ cells), the taking into account of the voltage drop inside the array is mandatory to explain the large $\mathrm{V}_{\mathrm{T}}$ spread. The next studies will apply this methodologies to write state, CHE programing and the quantification of extrinsic cells.

\section{REFERENCES}

[1] F. Pio, et al., US Patent n ${ }^{\circ} 6,128,219$, oct.3, 2000.

[2] P. Cappelletti, et al., Microelectron. Reliab., Vol.37, 1997.

[3] C. Le Roux, et al., Solid-State Electronics, Vol. 52, Dec. 2007.

[4] R. Djenadi, et al., Solid-State Electronics, Vol. 78, 2012.

[5] P. Canet, et al., Microelectron. Reliab., Vol. 53 No. 9-11,2013.

[6] P. Canet, et al., Microelectron. Reliab., Vol. 64, 2016.

[7] T. Kempf, et al., Accepted Proc. of IEEE IIRW, 2017. 